Max-Planck-Institut für demografische Forschung

Max Planck Institute for Demographic Research

Doberaner Strasse 114 - D-18057 Rostock · GERMANY

Tel +49 (0) 3812081 - 0; Fax +49 (0) 3812081 - 202;

http://www.demogr.mpg.de

MPIDR WORKING PAPER WP 2002-008

FEBRUARY 2002

Differences in Family Policy

and the Intergenerational Transmission

of Divorce:

A Comparison between the former

East and West Germany

Henriette Engelhardt (engelhardt@demogr.mpg.de)

Heike Trappe (trappe@mpib-berlin.mpg.de)

Jaap Dronkers (jaap.dronkers@iue.it)

This working paper has been approved for release by: Jan M. Hoem (hoem@demogr.mpg.de)

Head of the Laboratory of Contemporary European Fertility and Family Dynamics.

(C) Copyright is held by the authors.

Working papers of the Max Planck Institute for Demographic Research receive only limited review. Views or opinions expressed in working papers are attributable to the authors and do not necessarily reflect those of the Institute. 


\title{
Differences in Family Policy and the Intergenerational Transmission of Divorce: A Comparison between the former East and West Germany ${ }^{*}$
}

\author{
Henriette Engelhardt \\ Max Planck Institute for Demographic Research, Rostock \\ Heike Trappe \\ Max Planck Institute for Human Development, Berlin \\ Jaap Dronkers \\ European University Institute, Florence
}

February 20, 2002

* The authors would like to thank Gunnar Andersson, Francesco Billari, Josef Brüderl, Jan Hoem, Johannes Huinink, and Karl Ulrich Mayer for valuable comments and suggestions on an earlier draft. 


\title{
Differences in Family Policy and the \\ Intergenerational Transmission of Divorce: \\ A Comparison between the former East and West Germany
}

\begin{abstract}
The intergenerational transmission of the risk of divorce is a well-known long-term effect of divorce that has been found in many Western societies. Less known is the extent to which different family policies and divorce laws have an effect on the intergenerational transmission of divorce. In this paper, the division of Germany into two separate states from 1949 until 1990, with the consequent development of two very different family policies, is regarded as a natural experiment that enables us to investigate the effect of family policy on the mechanisms underlying the social inheritance of divorce. Data from respondents from the former East and West Germany participating in the German Life History Study are analyzed, using multivariate event-history methods. The results indicate that the strength of the intergenerational divorce transmission, when adjusted for differences in the divorce level, was lower in the East than in the West. Differences in marriage age and the timing of first birth, which are partial indicators of family policy, as well as differences in religion, could explain this effect. Furthermore, we found a tendency towards a reduction in the dynamics of divorce transmission over time, both in East and West Germany.
\end{abstract}




\section{Introduction}

Children of divorced parents get their marriage dissolved significantly more often than do otherwise comparable children of non-divorced parents. This intergenerational transmission of divorce risk is significant in several industrialized societies: the US, Australia, East and West Germany, and the Netherlands. ${ }^{1}$ These societies differ from one another in many respects, one of which being family policy. These differences might have an impact not only the shortterm effects of parental divorce on children but also on the long-term consequences. The way in which the similarities and differences among nations relate to the respective consequences of parental divorce for the children has not yet been systematically studied, despite the potential scientific and political importance of such a study (e.g. as a sound basis for the public debate on divorce).

By empirically analyzing differences in the intergenerational transmission of marital instability in the former Federal Republic of Germany (FRG/West Germany) and the former German Democratic Republic (GDR/East Germany), we aim to shed light in this article on the relevance of different family policies and divorce laws. During the 40 years of separation, the societal differences between the two parts of Germany were reinforced by the social order. Differing basic ideas about family formation and dissolution, as well as family policy incentives, contributed to this development. The resulting partial divergence of demographic processes was most obvious during the 1970s and 1980s, when social and family policies in the two countries were most sophisticated. (For family formation, see Huinink 1995; for divorce, see Wagner 1997.) Thus, the comparison of the intergenerational transmission of

\footnotetext{
${ }^{1}$ For the USA, see Amato \& Booth (1991), Bumpass \& Sweet (1972), Bumpass et al. (1991), Glenn \& Kramer (1987), Greenberg \& Nay (1982), Keith \& Finlay (1988), Kulka \& Weingarten (1979), McLanahan \& Bumpass (1988), Mueller \& Cooper (1986), Mueller \& Pope (1977), Pope \& Mueller (1976), Webster et al. (1995), Wolfinger (1999). For Australia, see Dronkers \& Hox (1998). For East Germany, see Diefenbach (1997), Wagner (1997). For West Germany, see Diefenbach (2000), Diekmann \& Engelhardt (1995, 1999), Engelhardt (2002), Wagner (1993, 1997). For the Netherlands, see Dronkers (1997), de Graaf (1996), Manting (1996).
} 
divorce is embedded in a quasi-experimental context. On the one hand, the two parts of Germany differed in family policy and ideology during the 40 years of separation. On the other hand, both parts resembled each other culturally more than any other European societies in a dual comparison. If family policy makes a difference in the upbringing of children, this should be visible in the long-term differential effects of parental divorce on children in the two Germanies.

One could argue that the former East Germany existed as a socialist society for only 40 years, a period that was too short to profoundly influence the intergenerational transmission of divorce. Neither parents nor children had lived their entire life under the socialist regime and neither could thus be influenced to the same extent than their West German counterparts by similar family policies. Despite the truth of this argument, the comparison is still worthwhile because no two other industrial societies with long-term differences in family policies are comparable to this extent. In addition, the transmission of divorce is being studied by focusing on the period during which the children of divorcees grow up, and this period coincides with the 40 years of separation of the two German societies.

[Figure 1 about here]

Regional differences in the level of divorce existed within Germany long before the founding of the GDR and the FRG in 1949 (see Figure 1). ${ }^{2}$ Wagner notes that the divorce rate has been higher in East Germany since the 1920s (1997: 119-120). However, little seems to be known about the reasons for this difference. It could be due to the different religious composition of the East and West German population that predates the division of Germany in 1949 (Gabriel 1989: 373). Figure 1 shows that after 1949, the differences between the East and West increased slightly. They were the greatest during the 1970s and the 1980s. The extreme peak in the West German curve in 1977/78 was due to the introduction of new legal regulations on

${ }^{2}$ The general divorce rate that is given in Figure 1 is a crude measure of the level of divorce. It is the only one available over a long period of time, though. 
divorce (see Table 1). After reunification there was a dramatic drop in divorce rates in East Germany, which has been attributed to the transfer of West German divorce regulations to the former GDR and to the overall feeling of insecurity (Wagner 1997). Probably more relevant in explaining the intergenerational transmission of divorce is the number of young children involved. This number was higher in the former East Germany than in West Germany from 1965 onwards and reached its peak in both countries around 1970. The decrease in the number of children of divorced parents thereafter was more pronounced in the West than in the East (Cromm 1998: 564; Wagner 1997: 122).

\section{Family policy in the former East and West Germany}

Based on comparative analysis of family policy in industrialized countries during the $20^{\text {th }}$ century, Gauthier developed four models of family policy that prevailed at the turn of the century (1996: 203). Within this framework the former East Germany would correspond mainly to the 'pro-natalist' model, whereas West Germany would be situated in the 'protraditional' model. A distinguishing feature of the former model is the desire to increase the fertility rate and the accompanying belief that such a goal requires government intervention. Emphasis is placed on reducing the obstacles to fertility, especially those concerning employment and family responsibilities. Characteristic of the pro-traditional model is the ostensible government endorsement of the family unit and the simultaneous encouragement of a family model with a single male breadwinner (Gauthier 1996).

Table 1 shows a summary of selected, important differences in family policy between East and West Germany. In East Germany, continuous full time employment of both men and women was seen as the main foundation of gender equality. By the late 1960s, the state recognized that women's increasing employment seemed to be associated with lower fertility rates. Therefore,

the state shifted its efforts to also include the support of working mothers. Extensive and inexpensive public child care, including after-school care and care for very young children, and other social support allowed women to stay in the workforce even during childbearing years. 
A great emphasis was placed on cash benefits (e.g. child allowance) but also on other support for employed mothers (e.g. child-illness leave, reduction in working hours for full-time employed mothers of two or more children). Marriage was seen as the foundation of the family but there was also generous support for single mothers. ${ }^{3}$ When marriages failed, divorce procedures were relatively uncomplicated and aimed at the independence of the former couple through their own employment. Generally, family policy was directed only towards women and did not attempt to redefine men's roles as fathers. East German family policy had two partly contradictory goals: the integration of women into full-time employment and the encouragement of childbearing. To achieve the latter, the state set incentives for people to get married early and to have children early. ${ }^{4}$ Those measures were quite effective in reducing the age at first birth across cohorts for women and men but not as effective at reducing the age at marriage because of the countervailing tendency to have a first child out of wedlock (Huinink 1995). We assume that those changes in demographic behavior did not have the effect of stabilizing marriages intended by government but rather an unintended destabilizing effect on marriages.

[Table 1 about here]

${ }^{3}$ The particular support for single mothers (e.g. paid sick leave for the first child and all subsequent children) contributed in fact to a situation where many parents postponed marriage until after the birth of the first child. This in turn had an impact on the wide acceptance of children born out of wedlock (Trappe 1995).

${ }^{4}$ Early marriage was encouraged by age-dependent interest-free marriage loans where the principal on the loan would be reduced with each additional child. When it was introduced in 1972, only people who were younger than 26 years old and were marrying for the first time were entitled. When the third child was born, parents received the full amount of the loan and were not required to pay anything back. Further, a unique bonus of roughly an average monthly salary was paid for the birth of each child. Another incentive for early family formation was the criteria for the allocation of apartments where young families had an advantage (Hinrichs 1992). The introduction of child care leave for the second child and children of a higher order, first introduced in 1976 and later extended to the first child in 1986, was a further incentive to have children early (Trappe 1995). 
During the time period under study in West Germany, social and family policies were dominated by the traditional male breadwinner model in which women worked full-time until they had children and returned to part-time work after a longer interruption (e.g. the tax system heavily weighted in favor of married and single income couples). Combining work and family was difficult for women due to the lack of public child care, the non-existence of a private child care market and the inconvenient school hours and opening times of many day care institutions. Instead of facilitating women's employment opportunities by providing services, the government gave preference to extended leave for child-care, which allowed mothers to stay at home with their young children, depending economically on their partners and on a flat rate, means-tested payment. During the time of their non-employment, women's entitlements were largely derived from their husbands' rights. Financial support for single parent families was modest and formed part of the general income support system (e.g. the increased benefit level of social assistance) and there were no specific measures to encourage single mothers' employment. There existed incentives for marriage when couples decided to have children, but not in any specific way for early family formation. When marriage failed, a divorce was relatively costly and carried high economic risks, especially for women with children (DiPrete 2001; Ruspini 1998).

One can conclude that married and divorced women with children in East Germany would be financially more independent of their (former) husbands or partners and that the economic and social position of mothers with children would not decline as much after divorce as in West Germany (Büchel \& Engelhardt 2000). Furthermore, due to their low costs, waiting times and simplicity the divorce procedures themselves might be less stigmatizing and stress-producing in East Germany (Berghahn \& Fritzsche 1991). 


\section{Theoretical link between divorce transmission and family policy}

The literature provides a variety of explanations for the association between parental and offsprings' divorce. Basically, five mechanisms have been identified as causal links: ${ }^{5}$ (1) The stress that accompanies parental divorce is a 'push' factor that often induces the children to leave the parental home early, get married early and have children at a young age thus raising their own risk of divorce (for the the stress argument, see Amato 2000, Amato 1993, McLanahan \& Bumpass 1988, Wallerstein \& Kelley 1980).(2) The socialization in the parental home causes children to develop certain attitudes and ways of behaving, making either the children of divorced parents less able to maintain a relationship later on, or causing them to leave an unsatisfactory relationship at an earlier stage than others (for the socialization argument, see Glenn \& Kramer 1987, Greenberg \& Nay 1982, Pope \& Mueller 1976). (3) The diminished economic circumstances that follow parental divorce affect the lives of the children negatively (through difficulties in educational and occupational attainment), thus increasing the children's own risk of getting divorced (for the economic deprivation argument, see McLanahan \& Bumpass 1988). (4) The stigma of parental divorce negatively affects the life opportunities of the children involved (for the stigmatization argument, see Spruijt 1993). (5) Parents and children have some common inherited personality traits that promote, or hinder, both the parent's and the children's divorces (for the genetic argument, see see Cramer 1993, Jockin et al. 1996, McGue \& Lykken 1992).

These mechanisms, or categories of intervening variables, do not logically exclude each other. It is very likely that there are interactions between the respective factors, for example, between economic disadvantages and unfavorable socialization conditions. Little is, however, known about the relative impact of the respective mechanisms because of the lack of appropriate data. Furthermore, the different mechanisms could operate at different times in the life course. The genetic argument might be the first mechanism, followed by a disadvantageous socialization

\footnotetext{
${ }^{5}$ However, Ní Bhrolcháin (2001) stresses that counterfactual analysis would be needed for a causal interpretation of this association.
} 
of the children of the divorced, and then simultaneously by stigmatization and economic deprivation. Eventually, the stress mechanism would also extend its influence.

The different family policies combined with four of the mechanisms underlying the social inheritance of divorce might explain possible differences in the strength of the relationship between parental and children's divorce risks in the former West and East Germany. In the following, the genetic argument is not considered because we assume that genetic characteristics of divorcees would not be very different in the two German states; furthermore, genetic traits and institutional differences should be unrelated to each other.

If the stress argument were valid, stress could work toward making the transmission effect weaker in East Germany. More liberal divorce laws would make divorce easier, less drawn out and thus less stress-producing for children. This in turn would reduce the negative outcomes often observed in relation to stressful parental divorce. However, we know that in the former East Germany the divorced couple and their children often had to share the same apartment for longer periods of time because of the continuous shortage of housing (Hinrichs 1992). This could also be a stress-producing factor that would then increase the transmission effect. In summary, it turns out to be difficult to predict the differences in the social inheritance of divorce between the two societies based on a divorce stress perspective.

If the socialization argument explains divorce transmission in part, it would impart a stronger transmission effect in the East because of the comparatively diminished emphasis on traditional norms of partnership and marriage. ${ }^{6}$ In the GDR the dual earner family was established early on by means of economic pressure. The idea of a mother as housewife was not supported by social policies. Instead, women's and men's economic independence was favored and thus the economic function of marriage was weakened over time (Dorbritz 1993). In addition, the increasing proportion of children born out of wedlock contributed to a relaxing

${ }^{6}$ Despite this process, family and partnership remained of high individual value in the GDR (Huinink \& Wagner 1995). 
of marital norms. Almost all mothers in the GDR were gainfully employed. After a divorce the children involved would therefore not face a dramatic change in their daily lives regarding their mother's presence. In the FRG it was more likely that women increased their labor force participation after divorce (Drobnič 2000). The role model of the divorced mother in the GDR might therefore have been less negatively viewed than in the FRG, where mothers of young children were expected to stay at home for longer periods of time. One could also argue that children who experience their parents' divorce as less problematic would not be as afraid of going through the same process themselves and would therefore show an increased tendency to get divorced in case of conflict. This would support the assumption of a stronger transmission effect in the East of Germany.

If the economic deprivation argument is valid, it should affect a weaker transmission of divorce in East Germany because day care for children was inexpensive and readily available. The generous support for employed mothers enabled divorced mothers, as well as other mothers, with dependent children to combine work and family simultaneously and to maintain an autonomous household. In contrast, given the insufficient supply of public child care in West Germany, the employment chances for women with youngchildren were less favorable (Büchel \& Engelhardt; Trappe \& Rosenfeld 2000). Therefore, children of divorced parents in West Germany might face more difficult economic circumstances and thus should be more prone to divorce than their East German counterparts.

If the stigmatization argument accounts for divorce transmission, one would also expect it to work toward a lower effect in the East because of the higher divorce rates and the liberal and inexpensive divorce procedures which make parental divorce less stigmatizing for children. With less stigmatization, the developmental and life opportunities of the children involved tend to be more advantageous. According to Wolfinger (1999), in the U.S. of the 20th century the level of intergenerational transmission of divorce has been declining as divorce has become 
more common and socially accepted, ${ }^{7}$ thereby decreasing the stigmatization of divorced parents and their children. In our case, we would expect a reduced transmission effect in the younger cohorts in the West as well as in the East. Furthermore, because of the more liberal family policy in East Germany, we would assume a faster decline of the transmission effect in the East than in the West.

Although the direction of the effect of the stress mechanism is indeterminate, and the socialization mechanism points in a positive direction, the economic deprivation and stigmatization arguments would predict less intergenerational transmission of divorce in East than in West Germany. In East Germany, more liberal divorce laws and a family policy allowing greater economic independence for women made divorce easier and less costly, which in turn caused less economic deprivation and less stigmatization.

Because of the anti-religious tradition in East Germany and the denominational composition of its population, one could argue that the transmission effect should be higher there than in West Germany because of the higher propensity for Protestants and non-religious individuals to get divorced. However, we consider the possible impact of religion on intergenerational divorce transmission to be an historically based structural effect and a more general effect of the political system and not an effect specifically related to different family policies.

Family policies have had an impact on lowering the barriers for divorce in both parts of Germany, probably more so in the East. One could even argue that family and employment policies in East Germany during the 1970s and 1980s reduced the barriers to divorce so drastically that the intergenerational transmission of divorce risk was to some extent undermined. This would support our expectation that the social inheritance of divorce risk would be lower in the East than in the West.

${ }^{7}$ This could also imply that the types of conflicts leading to divorce and experienced by children became less severe over time. 
A generally increased divorce risk resulting from the declining age of couples at the time of family formation was one of the unintended consequences of family policies in East Germany. Early family formation is known to result in an increased risk of divorce (Engelhardt 2002). An age at the time of first marriage and first birth (Huinink 1995) contributed to a situation in which children of divorced parents were probably not very different from children of nondivorced parents. The intergenerational transmission effect which is also influenced by marriage age and age at first birth is superimposed by the resulting overall increased divorce risk.

Although several studies of the former West Germany (e.g. Diefenbach 2000, Diekmann \& Engelhardt 1995, 1999, Engelhardt 2002, Wagner 1993) show an increased divorce risk for the offspring of divorced families, the evidence for East Germany is less clear. Using the life table method to analyze data from the 1994 German Family Survey, Diefenbach (1997) found a significantly increased divorce risk for children from divorced parents. Analyzing data from the 1996 Mannheim divorce survey, Babka von Gostomski (1998) finds no significant transmission effect for East Germany, using a multivariate Cox model. Both studies focus on East Germany after unification in 1990, and we know of only one study that examines the intergenerational divorce transmission in the two German states. Analyzing data from the German Life History Study, Wagner found that children of divorced parents have a significantly higher of getting divorced risk (110\%) than children of two-parent families in the West, as compared to only 60\% in the East (1997: 257-264). Wagner does not directly compare the transmission effect between the two parts of Germany, nor does he consider any intervening variables as possible mechanisms of transmission to account for the different levels of divorce transmission.

In this article, therefore, we will address the following questions: (1) Is the level of the intergenerational transmission of divorce in the former East Germany lower than in West Germany? (2) If so, can this difference be explained by the ways that family policy affect the mediative mechanisms of the transmission of divorce, i.e. the stress mechanism (a consequence being e.g. age at first marriage), the socialization mechanism (working through the religious 
affiliation of parents and children, parents education as proxy for labor force attachment), the economic deprivation mechanism (a consequence being e.g. educational level), or the stigmatization mechanism (working through the proportion divorced in the population)? (3) Does the level of intergenerational transmission of divorce risk decline over time both in West Germany and East Germany? (4) If so, is the decline of the transmission effect faster in the East than in the West?

\section{$4 \quad$ Data and Methods}

Our data stem from the German Life History Study (GLHS). The GLHS is based on random samples of the German residential adult population of certain birth cohorts. In West Germany 5,591 persons of the cohorts born in 1919-21, 1929-31, 1939-41, 1949-51, 1954-56 and 195961, and in East Germany 2,331 persons of the cohorts 1929-31, 1939-41, 1951-53 and 1959-61 were interviewed. ${ }^{8}$ Between 1949 and 1990, East and West Germany existed next to each other. Therefore, our analysis focuses on respondents of the birth cohorts born in 1939 through to 1961 who married before reunification in 1990. Further, we consider only first marriages because second and higher-order marriages differ in many aspects from first marriages and because the possible mechanisms of divorce transmission mentioned above do not refer explicitly to further marriages. Approximately $76.2 \%(n=2,646)$ of the respondents of these cohorts in West Germany and 91.5\% $(n=1,592)$ in East Germany entered a first marriage before 1990. The proportions of East and West Germans of those birth cohorts who married at least once in their lives corresponds to official statistics (Dorbritz 1990, Huinink 1995). By the end of $1989,11.0 \%$ of the West German and $17.3 \%$ of the East German respondents had divorced. ${ }^{9}$

\footnotetext{
${ }^{8}$ In the second half of the 1990s, life history data for East Germans born in 1971 and for West Germans born in 1964 and 1971 were collected. For more information on the data, see Brückner \& Mayer (1998).

${ }^{9}$ Survey studies generally underestimate divorce frequency due to systematic nonresponse and social desirability in response behavior (Sweet \& Bumpass 1992, Diekmann \& Klein 1991, Huinink \& Wagner 1995). The official estimation of the divorce rate by the Federal Bureau of Statistics is about 30 percent in 1995 (Hammes 1996: 774). The given
} 
Since final marriage duration at divorce is known only in the case of marriages dissolved before the survey (non-censored cases) but does not include marriages still existing (censored cases), conventional procedures such as simple table analyses or multivariate regression analyses cannot be used. Event-history or survival analysis provides consistent estimates of the covariate influences on the divorce risk, even if some of the observations at hand are censored cases.

To analyze the effects of the determinants on the divorce risk $r(t)$ we use the classical Cox model, in which the shape of the baseline divorce risk $r_{0}(t)$ is not modeled explicitly:

$$
r(t)=r_{0}(t) \exp \left\{\beta_{1} x_{1}+\beta_{2} x_{2} \ldots+\beta_{m} x_{m}\right\}=r_{0}(t) \alpha_{1}^{x_{1}} \alpha_{2}^{x_{2}} \ldots \alpha_{m}^{x_{m}} .
$$

Here $x_{1}, \ldots, x_{m}$ denote covariates while $\beta_{1}, \ldots, \beta_{m}$ and $\alpha_{1}, \ldots, \alpha_{m}$ are parameters to be estimated empirically, $\beta_{k}=\ln \left(\alpha_{k}\right) .\left(\alpha_{k}-1\right) \times 100$ can be interpreted as the percentage effect of covariate $k$ on the risk of divorce. If $\alpha_{k}>1\left(\alpha_{k}<1\right)$, there is a positive (negative) influence of a covariate on the risk of divorce. In the presence of censored observations, an application of the partial-likelihood method provides consistent and (asymptotically) normally distributed estimates for the $\alpha$-effects. Thus, the $\alpha$-effects are also subject to inferential statistical testing procedures. However, in the presence of a high percentage of censored observations, as presently is the case, the underlying proportional hazards assumption may be violated. We did some sensitivity analysis to confirm the robustness of the estimates from the Cox model. Estimations of the parametric log-logistic model and the sickle model yield almost the same results.

Some covariates can change value over the course of time. An indicator that a first child has arrived is a typical time-varying covariate. In order to estimate the effects of time-varying covariates, we use the episode splitting procedure. Marriage duration will always be split up

estimates are too high, however, because they also include second and higher-order marriages, and they have higher divorce rates. 
if the covariate changes, that is, if a child is born or if it passes the years 1977 and 1978 (to consider the impact of the reform in divorce law on divorce rates in West Germany). This procedure is universally applicable in parametric and semiparametric models and provides consistent estimates. We have used the TDA program for our analyses (Blossfeld \& Rohwer 1995).

Because of censoring at the interview, the duration offirst marriage is the difference between the year of the interview and the year of the first marriage for non-divorced and non-widowed respondents. If the interview occurred after 1989 (the beginning of the GDR's breakdown), then 1989 was substituted for the year of interview. For respondents divorced before 1990, the length of marriage is the difference between the year of their divorce and the year of their first marriage. For respondents widowed before 1990, the length of marriage is the difference between the year of their widowhood and the year of their first marriage.

The following variables are used in this analysis:

- $\quad$ The type of parental family is captured by four binary variables: (1) an indicator of growing up (up to age 16) with both parents (both parents), (2) growing up with one parent due to parental divorce or separation (divorced parents), (3) growing up with one parent due to the death of the father or mother (widowed parent), and (4) growing up with an unknown parent (unknown parent).

- The religious orientation of the respondent is expressed by three binary variables: catholic, protestant (and other religions), and no religion.

- $\quad$ The marriage age of the wife and husband is measured in integer years.

- If the first child was born before entering marriage, the child before marriage is coded 1 , otherwise 0 .

- $\quad$ The birth of the first child within the first marriage is entered as a time-dependent covariate $\left(1^{s t}\right.$ child $)$, which changes from 0 to 1 after the birth; for more details see below. 
- If the respondent's father or mother has an education at least at an average level for their part of Germany, the variables father/mother: good education are coded 1, otherwise 0 (two binaries)

- $\quad$ Three dummy variables are created for the marriage cohorts 1970-1979, 1980-1989, and before 1970.

- The educational level of a couple is captured by six dummy variables: wives'/husbands' education: low, middle, and high.

- If the educational level of the husband is higher or lower than that of the wife, the dummy variables husbands' education $\rangle /<$ wives' take a 1 . The reference category is the couples with an equal level of educational.

- If the respondent is from the former East Germany, the dummy GDR gets a 1, otherwise a 0 .

- The period effect of the divorce rates in West Germany is modeled by two timedependent covariates $(1977,1978)$, each of which changes from 0 to 1 when the marriage duration passes this year (see Figure 1).

The means of the covariates are listed in Table 2.

[Table 2 about here]

The compositions of respondents from East and West Germany differ in several aspects that could influence the level of the intergenerational transmission of divorce. Specifically, men and women were younger at first marriage in the East than in the West and had children prior to marriage more often than not. Only $4.3 \%$ of all East German respondents remained childless during the period under observation $(=100-72.1-23.6)$ in comparison to $17.3 \%(=100-$ 75.6 - 7.1) in West Germany. In addition, East German respondents were less often Catholic or Protestant, and much more often had no religious affiliation. However, this is more a structural effect corresponding to historical developments and political pressure in the East than a consequence of different family policies. We consider the differences in marriage age and fertility as important consequences of different family policies in East and West Germany. 


\section{$5 \quad$ Results}

We first consider the proportion of intact marriages by marriage duration using the 'life table' method. For an initial test of the transmission hypotheses in West and East Germany, we compute separate divorce tables according to the type of family of origin. Figure 2 and 3 are graphical depictions of the course of intact marriage proportions for the four parental-family categories. The different lengths of the risk curves for the West and the East are due to the cohort design of the GLHS: While all East German cohorts were interviewed in 1991/92 and the data cut off at the end of 1989, the West German birth cohorts from 1939-41 and 1949-51 had already been interviewed around 1982. Interviews with respondents of the West German birth cohorts from 1954-56 and 1959-61 were conducted in 1989. On average, those differences in observation periods result in longer curves for respondents from the former East Germany.

[Figure 2 and 3 about here]

As Figure 2 shows, there is an extremely clear effect for the 'divorced parents' category in West Germany. If the respondent comes from a divorced family, it is much more likely that his or her first marriage will end in divorce than for the other parental-family categories. At a marriage duration of ten years, the risk of divorce for children whose parents were divorced is more than twice as high as for children who grew up in families with both parents, a widowed parent, or an unknown parent. Further, one can see that risk differences between the three other types of parental families are small. The difference between the four survival rates is highly significant, so there is clear evidence that West German marriages are affected by the social inheritance of divorce risk.

For East Germany (Figure 3), we also observe a higher proportion of marriages ending in divorce for 'divorce orphans', with smaller (and insignificant) distances between the survival curves for the different family types than in the West. But this is just a first hint at the adequacy of the hypothesis of the lower intergenerational transmission effect in East Germany. Although 
the proportion of divorced marriages is somewhat higher in the West, the overall difference in the survival rates for respondents with divorced parents in East and West Germany is not significant. Therefore, at first glance, it looks as if the hypothesis that there exist different transmission effects in East and West Germany must be rejected.

This need not be the final conclusion, however. It could be that an existing difference in the level of the intergenerational transmission effect is hidden by the overall higher divorce rate in the former East Germany (see Figure 1). To examine the net difference in divorce transmission, we therefore take into account the discrepancy in the levels of divorce rates.

This can be done with the multivariate Cox regression described above. The higher East German divorce level is controlled by a simple dummy ('GDR'). To test whether the intergenerational transmission effect is smaller in the former East than in the former West, an interaction variable indicating an East German respondent with divorced parents ('GDR*divorced parents') is added. The semiparametric estimates are listed in Table 3 (Model 1). The effect of the interaction variable 'GDR*divorced parents' is significant and indicates that the transmission is lower in East than in West Germany. The interaction effects of Table 3 are summarized in Table 4 (panel 1). Although persons with intact parental families from East Germany have a $26 \%$ higher divorce risk than respondents from West Germany, East German persons with divorced parents still have an increased risk of divorce $(+28 \%)$ compared with respondents from intact families. But West German individuals with divorced parents have a significantly higher increase $(132 \%)$ in the divorce risk in comparison to respondents from intact families. This result confirms the hypothesis that there exist a lower intergenerational divorce transmission effect in the former East Germany.

[Table 3 and 4 about here]

Let us now turn to the second question, namely whether this difference can be explained by indicators of family policies (marriage age and age at first birth) and overall societal differences (religious composition). Taking this into account, we now consider how the GDR effect (as a 
control for the divorce level) and the interaction effect of GDR and divorced parents (as a control for the intergenerational transmission of divorce) change when we control for covariates. Adding the covariates separately to the base Model 1 of Table 3 enables us to distinguish which factors are responsible for the significant interaction effect. In the Models 2 to 4 we add important characteristics of the couple as well as individual characteristics, and in Model 5 to 7 we control for specific covariates which are at least partly the outcome of family and social policy. Although the marriage cohort (Model 2) and the education of the respondents' father (Model 3) have a significant effect on the risk of divorce, they do not change the overall picture regarding the lower intergenerational transmission of divorce in East Germany.

Pursuing our main interest, we note that the significance of the interaction effect disappears when we control for specific family and social policy related covariates. Controlling for the different religious affiliation in both German societies (Model 5) reduces the intergenerational transmission effect, rendering it insignificant. East Germans with divorced parents compared to East Germans from intact families now have a significantly lower risk of getting divorced $(+24 \%)$ than corresponding West Germans $(+104 \%$, see Table 4$)$. There is no longer a significant difference between East German respondents from intact families and divorced families. Underlying this result is the lower divorce risk for Protestants when compared to persons without religious affiliation in East Germany $(-37.1 \%=1-(0.405 * 1.553))$ and in West Germany $(-59.5 \%=1-0.405)$, as well as the lower divorce risk for Catholics as compared with nonreligious individuals in West Germany $(-66.6 \%=1-0.334)$. However, religion is so strongly associated with differences in political systems that one cannot disentangle its impact on intergenerational transmission of divorce from possible policy effects. Therefore, we do not consider religion in our final model.

Taking into account the differences in the marriage age of the bride and groom in East and West Germany (Model 6) and the timing of first birth before and within the marriage (Model 7), one finds a comparable impact on the intergenerational transmission of divorce risk in East Germany. The lower social inheritance of divorce in the East is reduced to insignificance. 
Wives' marriage ages in East Germany seem to be of special importance here because of their significant negative impact on divorce risk. In regards to the first birth within the marriage, there is a significantly reduced divorce risk for respondents in West Germany $(-60.1 \%)$ as compared to respondents in West Germany without a child birth after marriage. The corresponding effect of first births in the former East Germany is $-48.6 \% \quad(=1$ $(0.399 * 1.287))$, which is relatively low compared to West Germany. ${ }^{10}$

We also take into account the period effect of the change in divorce laws for West German respondents by adding two corresponding time-dependent covariates (Model 8). The estimated effects show a definite decrease in the divorce risk in 1977 and a significant increase after 1978 caused by a change in the divorce law (see Figure 1 and Table 1). Taking all influences on the risk of divorce discussed above together - except the religious composition - (Model 9) the comparably higher East German level of divorce increases and the lower intergenerational transmission of divorce in the East as compared to the West is no longer significant. As mentioned above, this lower intergenerational transmission of divorce risk is largely due to the impact of the couple's age at marriage and the timing of first birth. The difference in the intergenerational transmission of divorce can be explained by differences in those covariables which are at least partially the result of national differences in family policy.

[Table 5 and 6 about here]

Finally, let us turn to the question whether the strength of the intergenerational transmission of divorce has been declining, either in West or East Germany. We estimate separate Cox models for the West and the East and then add two terms in which the family structure of origin is allowed to interact with the marriage cohort. These interaction terms allow us to ascertain the presence of time trends in the intergenerational transmission of divorce (Table 5).

\footnotetext{
${ }^{10}$ However, the intergenerational dicorce transmission is not due to a transmission from parental age at marriage to child's age at marriage. The respective correlation between the mothers' and daughters', as well as between the fathers' and sons', marriage age is not significant.
} 
Compared to the marriage cohorts with divorced parents before 1970, respondents with divorced parents who married between 1970-79 have a reduced divorce risk. Comparable respondents of the marriage cohort 1980-89 have an even lower divorce risk in both East and West Germany. More specifically, in West Germany the effect declines from $231 \%$ to $146 \%$ to $56 \%$ and in East Germany from $73 \%$ to $24 \%$ to $-30 \%$ (Table 6). Although the effects are not significant, there seems to be at least a tendency towards a reduction in the dynamics of divorce transmission over time. However, there is no clear evidence for a faster decline in the former East Germany than in West Germany.

\section{Discussion}

In accordance with our expectations, the analysis shows that the strength of the intergenerational transmission of divorce, adjusted for the difference in divorce level, was lower in the former East than in the West Germany (question 1). The difference emerges because of a highly significant transmission effect for children from divorced families in West Germany but not for those from East Germany (Table 5). This suggests that differences in family policy and societal conditions between the two countries contributed to a lower level of intergenerational transmission of divorce in East Germany. One could even argue that the 'disappearance' of the transmission effect in the East has been partly an effect of a family policy that contributed to an overall reduction of the barriers for divorce, independent of the family of origin.

What could be said about the mechanisms that underlie this difference (question 2)? Which impact can be attributed to differences in family policy and which to structural differences? One of the important influences on the risk of getting divorced is the respondent's religious affiliation. If one takes into account the higher proportion of Catholics and Protestants in West Germany and the higher proportion of non-religious individuals in East Germany, there is no longer a difference in strength of the intergenerational transmission of divorce. We consider the difference in religiousity to be an important characteristic of the historically based, socio- 
cultural composition of the population. It is also an effect of the political system, as far as the increasing proportion of the population without religious affiliation is concerned. Because religiosity is largely transmitted form parents to children, the religious composition also influences the social inheritance of divorce.

The second important mechanism underlying the difference in the transmission effect between both countries is the marriage age of the husband and wife. The wife's age at first marriage seems to be especially important in reducing the transmission effect in East Germany as well as reducing the control variable for the higher divorce level to an insignificant level. In sum, the lower the woman's age at marriage the higher the respondent's risk of getting divorced. The differences between 'divorce orphans' from East and West Germany as well as the difference in divorce level diminish when controlled for marriage age. A possible explanation is the overall lower age at the time of their first marriage in East Germany, which leads to an increased divorce risk for all respondents, irrespective of whether their parents are divorced or not. Compared to West Germany, age at first marriage was significantly lower for both women and men in East Germany. We consider the comparably low marriage age a consequence of GDR family policy. It was part of the pro-natalistic aim in the 1970s and 1980s to set incentives for people to marry early, for example, via age-dependent interest-free marriage loans whereby the pay-back would be reduced with each child. Thus one can consider the comparably high divorce rate in East Germany as being strongly affected by family policies. It is interesting to note that when women had divorced parents, their age at first marriage in East Germany was slightly higher than the age of comparable women from intact families (Table 2). This suggests that there is some evidence in favor of the stress argument. If parental divorce procedures in East Germany were less stressful for the children than those in West Germany, there would be reason to assume that parental divorce did not serve as a specific 'push' factor for children's transition to adulthood.

The last important influence on the differences between the transmission effect in the two German societies is the timing of first birth. Previous research has shown that having a first child before the first marriage increases divorce-risk, whereas a first child born within the first 
marriage has a stabilizing influence (Wagner 1997). In our multivariate analyses based on different model specifications, the birth of a first child before marriage had no significant impact on the risk of getting divorced, whereas the birth of a first child within marriage decreased the risk of divorce considerably (see also Brüderl et al. 1997). The timing of first birth explains part of the lower intergenerational transmission of divorce in East Germany. In both countries, women and men with divorced parents were somewhat more likely than other persons to have their first child before first marriage -East Germans being about three times more likely than their West German counterparts to have a child before the first marriage. In East Germany there was a growing tendency across birth cohorts towards premarital birth, which was promoted in part by pro-natalistic family policies that gave special support to single mothers (Trappe 1995: 108ff). It is interesting to note that this trend obviously did not increase the risk of getting divorced. East German women and men were generally more likely to have a child and to have a first child earlier in their lives than in West Germany (Huinink 1995: 229ff). As a consequence, the difference in the transmission effect for 'divorce orphans' of the two countries was reduced to insignificance whereas the control variable for the higher divorce level in East Germany was actually strengthened. In East Germany, early childbirth was encouraged through special support for mothers still in training or studying. Our analyses therefore reveal a more complex picture of the impact of family policy on the two German societies and on the strength of the social inheritance of divorce, suggesting that differences in important demographic transitions in life were crucial underlying mechanisms.

In accordance with the stigmatization mechanism, we expected a decline in the dynamics of intergenerational transmission of divorce in both parts of Germany, and even a faster decline in East Germany (questions 3 and 4). We found at least a tendency towards a reduction in the time trends of intergenerational transmission in both societies but no strong evidence for a faster decline in the East than in the West. There may have been less stigmatization for younger generations in East Germany, but it had not yet resulted in a considerably faster decrease in the social inheritance of divorce. 
As we have shown, family policies and divorce laws do affect the intergenerational transmission of divorce. Nevertheless, the interrelations between family policy and socialization, stress, economic deprivation, and stigmatization are not yet fully understood. Better indicators are necessary to explain the relative impact of family policies on the intervening mechanisms of divorce transmission. 


\section{References}

Amato, Paul R. Children's Adjustment to Divorce: Theories, Hypotheses, and Empirical Support. Journal of Marriage and the Family, 1993, 55: 23-38.

Amato, Paul R. The Consequences of Divorce for Adults and Children. Journal of Marriage and the Family, 2000, 62: 1269-1287.

Amato, Paul R. and Alan Booth. Consequences of Parental Divorce and Marital Unhappiness for Adult Well-Being. Social Forces, 1991, 69: 905-914.

Babka von Gostomski, Christian. Machen Kinder Ehen glücklich? Eine empirische Untersuchung mit der Mannheimer Scheidungsstudie zum Einfluß von Kindern auf das Scheidungsrisiko. Zeitschrift für Bevölkerungswissenschaft, 1998, 23: 151-177.

Berghahn, Sabine and Andrea Fritzsche. Frauenrecht in Ost und West. 1991, Berlin: Basisdruck.

Blossfeld, Hans-Peter and Götz Rohwer. Techniques of Event History Modeling: New Approaches to Causal Analysis. 1995, Hillsdale, N.J.: Lawrence Erlbaum.

Brückner, Erika and Karl Ulrich Mayer. Collecting Life History Data. Experiences From the German Life History Study. In: J. Z. Giele and G. H. Elder, editors. Methods of Life Course Research: Qualitative and Quantitative Approaches. 1998, Thousand Oaks, CA: Sage: $152-181$.

Brüderl, Josef, Andreas Diekmann and Henriette Engelhardt. Erhöht eine Probeehe das Scheidungsrisiko? Eine empirische Untersuchung mit dem Familiensurvey. Kölner Zeitschrift für Soziologie und Sozialpsychologie, 1997, 49: 205-222.

Büchel, Felix and Henriette Engelhardt. Missing the Partner and His Earnings: Income Situation and Labour Market Participation of Single Mothers in West and East Germany. In: R. Anker, B. Garcia Guzman and A. Pinnelli, editors. Women in the Labour Market in Changing Economies: Demographic Issues. Forthcoming, Oxford: Oxford University Press.

Bumpass, Larry L., Teresa Castro Martin and James A. Sweet. The Impact of Family Background and Early Marital Factors on Marital Disruption. Journal of Family Issues, 1991, 12: 22-42.

Bumpass, Larry L. and James A. Sweet. Differentials in Marital Instability. American Sociological Review, 1972, 37: 754-766.

Cramer, Duncan. Personality and Marital Dissolution. Personality and Individual Differences, 1993, 14: 605-607.

Cromm, Jürgen. Familienbildung in Deutschland: Soziodemographische Prozesse, Theorie, Recht und Politik unter besonderer Berücksichtigung der DDR. 1998, Opladen: Westdeutscher Verlag.

Diefenbach, Heike. Intergenerationale Scheidungstransmission in Deutschland: Relevanz und Erklärungsansätze. Zeitschrift für Rechtssoziologie, 1997, 18: 88-105.

Diefenbach, Heike. Intergenerationale Scheidungstransmission in Deutschland: Die Suche nach dem "missing link" zwischen Ehescheidung in der Elterngeneration und Ehescheidung in der Kindgeneration. 2000, Würzburg: Ergonverlag. 
Diekmann, Andreas and Henriette Engelhardt. Die soziale Vererbung des Scheidungsrisikos. Eine empirische Untersuchung der Transmissionshypothese mit dem deutschen Familiensurvey. Zeitschrift für Soziologie, 1995, 24: 215-228.

Diekmann, Andreas and Henriette Engelhardt. The Social Inheritance of Divorce: Effects of Parent's Family Type in Postwar Germany. American Sociological Review, 1999, 64: 783-793.

Diekmann, Andreas and Thomas Klein. Bestimmungsgründe des Ehescheidungsrisikos: Eine empirische Untersuchung mit den Daten des sozioökonomischen Panels. Kölner Zeitschrift für Soziologie und Sozialpsychologie, 1991, 43: 271-290.

DiPrete, Thomas A. Life Course Risks, Mobility Regimes, and Mobility Consequences: A Comparision of Sweden, Germany, and the U.S. DIW Discussion Paper No. 255, 2001, Berlin: Deutsches Institut für Wirtschaftsforschung.

Dorbritz, Jürgen. Familienstandstafeln für die DDR (Eheschließungen Lediger und Ehescheidungen in der Perioden- und Kohortenmessung). In: Bundesinstitut für Bevölkerungsforschung, editor. Materialien zur Bevölkerungswissenschaft, Heft 65. 1990, Wiesbaden.

Dorbritz, Jürgen. Sozialer Systemwandel und die Folgen für die Familienbildung. Berliner Journal für Soziologie, 1993, 3: 355-368.

Drobnič, Sonja. The Effects of Children on Married and Lone Mothers' Employment in the United States and (West) Germany. European Sociological Review, 2000, 16: 137-157.

Dronkers, Jaap. Zoals de ouden zongen piepen de jongen. Intergenerationele overdracht van de kans op scheiding in Nederland. Mens en Maatschappij, 1997, 72: 146-165.

Dronkers, Jaap and Joop Hox. The Importance of Family and Education for Divorce Risks of Siblings: an Australian Example. Amsterdam: SCO-Kohnstamm Instituut. Paper presented at the European Research Conference 'European Societies or European Society? Inequality and Social Exclusion in Europe: the Role of the Family and Social Networks'. Castelvecchio di Pascoli, Italy, 3-7 April 1998.

Engelhardt, Henriette. Zur Dynamik von Ehescheidungen: Theoretische und empirische Analysen. 2002, Berlin: Duncker \& Humblot (forthcoming).

Gabriel, Karl. Kirchen/Religionsgemeinschaften. In: Bernhard Schäfers and Wolfgang Zapf, editors. Handwörterbuch zur Gesellschaft Deutschlands. 1998, Opladen: Leske + Budrich: 371-382.

Gauthier, Anne Hélène. The State and the Family. A Comparative Analysis of Family Policies in Industrialized Countries. 1996, Oxford: Clarendon Press.

Gerlach, Irene. Familie und staatliches Handeln. Ideologie und politische Praxis in Deutschland. 1996, Opladen: Leske + Budrich.

Glenn, Norval D. and Kathryn B. Kramer. The Marriages and Divorces of the Children of Divorce. Journal of Marriage and the Family, 1987, 49: 811-825.

Graaf, Arie de. De invloed van echtscheiding van de ouders op relaties van jongeren. Maandstatistiek van de Bevolking, 1996, 7-12.

Greenberg, Ellen F. and W. Robert Nay. The Intergenerational Transmission of Marital Instability Reconsidered. Journal of Marriage and the Family, 1982, 44: 335-347.

Hammes, Winfried. Ehescheidungen 1995, Wirtschaft und Statistik, 1996, 12: 770-776. 
Hinrichs, Wilhelm. Wohnungsversorgung in der ehemaligen DDR - Verteilungskriterien und Zugangswege. WZB-Papier, 1992, P 92-105, Berlin: Wissenschaftszentrum.

Huinink, Johannes. Warum noch Familie? Zur Attraktivität von Partnerschaft und Elternschaft in unserer Gesellschaft. 1995, Frankfurt: Campus.

Huinink, Johannes and Michael Wagner. Partnerschaft, Ehe und Familie in der DDR. In: Huinink Johannes et al., editors. Kollektiv und Eigensinn. 1995, Berlin: Akademie Verlag: 145-188.

Jockin, Victor, Matt McGue and David T. Lykken. Personality and Divorce: A Genetic Analysis. Journal of Personality and Social Psychology, 1996, 71: 288-299.

Keith, Verna M. and Barbara Finlay. The Impact of Parental Divorce on Children's Educational Attainment, Marital Timing, and Likelihood of Divorce. Journal of Marriage and the Family, 1988, 50: 797-809.

Kulka, Richard A. and Helen Weingarten. The Long-Term Effects of Parental Divorce in Childhood in Adult Adjustment. Journal of Social Issues, 1979, 35: 50-78.

Manting, Dorien. The Changing Meaning of Cohabitation and Marriage. European Sociological Review, 1996, 12: 53-65.

McGue, Matt and David T. Lykken. Genetic Influence on Risk of Divorce. Psychological Science, 1992, 3: 368-372.

McLanahan, Sara and Larry Bumpass. Intergenerational Consequences of Family Disruption. American Journal of Sociology, 1988, 94: 130-152.

Mueller, Charles W. and Hallowell Pope. Marital Instability: A Study of its Transmission between Generations. Journal of Marriage and the Family, 1977, 39: 83-92.

Mueller, Daniel P. and Philip W. Cooper. Children of Single Parent Families: How They Fare as Young Adults. Family Relations, 1986, 35: 169-176.

Ní Bhrolcháin, Máire. 'Divorce Effects' and Causality in the Social Sciences. European Sociological Review, 2001, 17: 33-57.

Pope, Hallowell and Charles W. Mueller. The Intergenerational Transmission of Marital Instability: Comparisons by Race and Sex. Journal of Social Issues, 1976, 32: 49-66.

Ruspini, Elisabetta. Living on the Poverty Line: Lone Mothers in Belgium, Germany, Great Britain, Italy and Sweden. Working Paper No. 28, 1998, Mannheim: Mannheimer Zentrum für Europäische Sozialforschung.

Spruijt, Ed. Volwassen worden in een kerngezin, eenoudergezin of stiefgezin. In: M. du Bois-Reymond and J. de Jong Gierveld, editors. Volwassen worden. Generaties toen en nu: transities in de levensloop. 1993, Houten/Zaventem: Bohn Stafleu Van Loghum: 73-92.

Sweet, James A. and Larry L. Bumpass. Disruption of Marital and Cohabitation Relationships: A Social-Demographic Perspective. In: T. Orbuch, editor. Close Relationship Loss: Theoretical Approaches. 1992, New York: Springer: 67-89.

Trappe, Heike. Emanzipation oder Zwang? Frauen in der DDR zwischen Beruf, Familie und Sozialpolitik. 1995, Berlin: Akademie Verlag.

Trappe, Heike and Rachel A. Rosenfeld. How Do Children Matter? A Comparison of Gender Earnings Inequality for Young Adults in the Former East Germany and the Former West Germany. Journal of Marriage and the Family, 2000, 62: 489-507. 
Wagner, Michael. Soziale Bedingungen des Ehescheidungsrisikos aus der Perspektive des Lebensverlaufs. In: Andreas Diekmann and Stefan Weick, editors. Der Familienzyklus als sozialer Prozess. Bevölkerungssoziologische Untersuchungen mit den Methoden der Ereignisanalyse. 1993, Berlin: Duncker \& Humblot: 372-393.

Wagner, Michael. Scheidung in Ost- und Westdeutschland. Zum Verhältnis von Ehestabilität und Sozialstruktur seit den 30er Jahren. 1997, Frankfurt: Campus.

Wallerstein, Judith S. and Joan B. Kelly. Surviving the Breakup: How Children and Parents Cope with Divorce. 1980, New York: Basic Books.

Webster, Pamela S., Terri L. Orbuch and James S. House. Effects of Childhood Family Background on Adult Marital Quality and Perceived Stability. American Journal of Sociology, 1995, 101: 404-432.

Wolfinger, Nicholas H. Trends in the Intergenerational Transmission of Divorce. Demography, 1999, 36: 415-420. 
Table 1: Family policy in the former East and West Germany until 1989

\begin{tabular}{|c|c|}
\hline East Germany & West Germany \\
\hline \multicolumn{2}{|c|}{ Family and employment } \\
\hline $\begin{array}{l}\text { Employment of women and men as main } \\
\text { foundation of their equality (e.g. individual } \\
\text { taxation of wives' and husbands' earnings) } \\
\text { - Continuous employment of women even during } \\
\text { childbearing years made possible by extensive } \\
\text { public child care and other social support } \\
\text { Marriage as foundation of the family but also } \\
\text { monetary and non-monetary support for single } \\
\text { mothers, mothers still in education and parents } \\
\text { with many children (e.g. more paid sick leave } \\
\text { for children) } \\
\text { - Generous regulations for child care leave with } \\
\text { far reaching rights of job return and extended } \\
\text { child care policies } \\
\rightarrow \text { Weakening of marriage as economic institution } \\
\text { via social policies }\end{array}$ & $\begin{array}{l}\text { - Male breadwinner model with continuously } \\
\text { employed men and partially employed women } \\
\text { (e.g. joint taxation of wives' and husbands' } \\
\text { earnings) } \\
\text { - Sequencing of employment and family with } \\
\text { longer interruptions and return to part-time } \\
\text { work while children were small } \\
\text { - Social support of marriage as foundation of the } \\
\text { family and basically monetary support for lone } \\
\text { mothers, support of wives during times of their } \\
\text { non-employment (e.g. social insurance via } \\
\text { husband) } \\
\text { - } \begin{array}{l}\text { Extended child care leave with a flat rate } \\
\text { payment and low provision of child care }\end{array} \\
\rightarrow \quad \begin{array}{l}\text { Supporting of marriage as economic institution } \\
\text { via social policies }\end{array}\end{array}$ \\
\hline \multicolumn{2}{|c|}{ Family formation } \\
\hline $\begin{array}{l}\text { Financial incentives for early marriage (e.g. } \\
\text { interest free marriage loan, easier access to } \\
\text { dwellings) } \\
\text { Incentives for early childbearing (e.g. reduced } \\
\text { repayment rate of marriage loan) } \\
\text { Relatively generous support of families with } \\
\text { children (e.g. child allowance) } \\
\rightarrow \quad \text { Family policies with pro-natalist aim }\end{array}$ & $\begin{array}{l}\text { - No particular incentives for early marriage and } \\
\text { early childbearing } \\
\text { Moderate financial support of families with } \\
\text { children (e.g. tax reduction, child allowance) } \\
\text { while at the same time encouraging a relatively } \\
\text { traditional division of labor within families } \\
\rightarrow \text { Family policies with pro-traditional aim }\end{array}$ \\
\hline \multicolumn{2}{|c|}{ Divorce regulations } \\
\hline $\begin{array}{l}\text { Since } 1948 \text { divorce procedure in court without } \\
\text { lawyers } \\
\text { No-fault divorce law since 1955, disruption of } \\
\text { marriage as sufficient ground for divorce only } \\
\text { short term and low alimentation rights for } \\
\text { women and clear rules for child support } \\
\text { - General rule: mothers got custody of their } \\
\text { children } \\
\text { - Problem: divorcees often lived in the same } \\
\text { apartment because of shortage of apartments } \\
\rightarrow \text { Basic idea: women should be independent of } \\
\text { their former husbands after divorce by their } \\
\text { own employment }\end{array}$ & $\begin{array}{l}\text { - Until } 1977 \text { fault divorce law from } 1900 \text { with } \\
\text { lawyers } \\
\text { - After } 1977 \text { a } 1 \text { year separation as sufficient } \\
\text { ground to divorce } \\
\text { - Strong influence of the court on the long term } \\
\text { alimentation rights for women (e.g. old age) } \\
\text { and children } \\
\text { - High costs of divorce procedures } \\
\text { - General practice: mothers got custody of their } \\
\text { children (joint custody possible) } \\
\rightarrow \text { Basic idea: women and children should not be } \\
\text { extremely worse off after divorce }\end{array}$ \\
\hline
\end{tabular}

Source: Berghahn \& Fritzsche (1991), Gerlach (1996: 205ff), Trappe (1995: 40ff), Wagner (1997: 157ff). 
Table 2: Means of the covariates

\begin{tabular}{|c|c|c|c|c|c|}
\hline & \multicolumn{3}{|c|}{ All } & \multicolumn{2}{|c|}{ With Divorced Parents } \\
\hline & FRG & GDR & Diff. & FRG & GDR \\
\hline Both parents $(=1,0$ else $)$ & $80.8 \%$ & \multicolumn{2}{|c|}{$75.2 \% * * *$} & & \\
\hline Divorced parents $(=1,0$ else $)$ & $4.8 \%$ & \multicolumn{2}{|c|}{$7.7 \% * * *$} & & \\
\hline Widowed parent ( $=1,0$ else $)$ & $12.9 \%$ & \multicolumn{2}{|c|}{$14.0 \%$} & & \\
\hline Unknown parent $(=1,0$ else $)$ & $1.5 \%$ & \multicolumn{2}{|c|}{$3.1 \% * *$} & & \\
\hline Married 1946-69 (=1, 0 else $)$ & $27.0 \%$ & \multicolumn{2}{|c|}{$33.7 \% * * *$} & $25.4 \%$ & $29.3 \%$ \\
\hline Married 1970-79 ( $=1,0$ else $)$ & $40.9 \%$ & \multicolumn{2}{|c|}{$36.3 \% * *$} & $44.4 \%$ & $39.0 \%$ \\
\hline Married 1980-89 (=1, 0 else $)$ & $32.1 \%$ & \multicolumn{2}{|c|}{$30.0 \%$} & $30.2 \%$ & $31.7 \%$ \\
\hline Father: good education $(=1,0$ else $)$ & $15.7 \%$ & \multicolumn{2}{|c|}{$14.5 \%$} & $15.1 \%$ & $17.1 \%$ \\
\hline Mother: good education ( $=1,0$ else $)$ & $11.4 \%$ & \multicolumn{2}{|c|}{$9.2 \% *$} & $15.9 \%$ & $13.8 \%$ \\
\hline Husbands' education: low & $68.3 \%$ & \multicolumn{2}{|c|}{$53.4 \% * * *$} & $70.5 \%$ & $45.1 \% * * *$ \\
\hline Husbands' education: middle & $16.8 \%$ & \multicolumn{2}{|c|}{$33.2 \% * * *$} & $18.0 \%$ & $45.1 \% * * *$ \\
\hline Husbands' education: high & $14.9 \%$ & \multicolumn{2}{|c|}{$13.4 \%$} & $11.5 \%$ & $9.8 \%$ \\
\hline Wives' education: low & $67.4 \%$ & \multicolumn{2}{|c|}{$50.2 \% * * *$} & $66.2 \%$ & $36.1 \% * * *$ \\
\hline Wives' education: middle & $22.2 \%$ & \multicolumn{2}{|c|}{$39.7 \% * * *$} & $26.6 \%$ & $56.4 \% * * *$ \\
\hline Wives' education: high & $10.3 \%$ & \multicolumn{2}{|c|}{$10.0 \%$} & $7.2 \%$ & $7.5 \%$ \\
\hline Husbands' educ. $=$ wives' $(=1,0$ else $)$ & $65.7 \%$ & \multicolumn{2}{|c|}{$64.2 \%$} & $64.3 \%$ & $66.7 \%$ \\
\hline Husbands' educ.> wives' ( $=1,0$ else) & $17.2 \%$ & \multicolumn{2}{|c|}{$15.9 \%$} & $18.2 \%$ & $13.0 \%$ \\
\hline Husbands' educ. <wives' (=1, 0 else) & $17.1 \%$ & $19.9 \%$ & & $17.5 \%$ & $20.3 \%$ \\
\hline Catholic (=1, 0 else $)$ & $45.2 \%$ & $4.3 \%$ & $7 * * *$ & $38.9 \%$ & $2.4 \% * * *$ \\
\hline Protestant (=1, 0 else $)$ & $44.7 \%$ & 26.79 & $\% * * *$ & $41.3 \%$ & $18.7 \% * * *$ \\
\hline No religion $(=1,0$ else $)$ & $10.1 \%$ & $69.0 \%$ & $7 * * *$ & $19.8 \%$ & $78.9 \% * * *$ \\
\hline Husbands' marriage age (years) & 25.4 & 24.2 & $* * *$ & 25.6 & 23.9 \\
\hline Wives' marriage age (years) & 22.6 & 21.9 & $* * *$ & 21.7 & 22.1 \\
\hline Child before marriage ( $=1,0$ else $)$ & $7.1 \%$ & $23.6 \%$ & $\% * * *$ & $12.7 \%$ & $25.2 \% *$ \\
\hline $1^{\text {st }}$ child in marriage $(=1,0$ else $)$ & $75.6 \%$ & 72.19 & & $70.6 \%$ & $69.9 \%$ \\
\hline Divorces & $11.0 \%$ & $17.3 \%$ & \% $* * *$ & $22.2 \%$ & $19.5 \%$ \\
\hline Number of marriages & 2646 & 1592 & & 126 & 123 \\
\hline
\end{tabular}

Notes: *** significant for $\mathrm{p}=.001$; ** significant for $\mathrm{p}=.01$; * significant for $\mathrm{p}=.05$ (two tailed test). Means of the dummy variables are the proportions of the 1-coded category. 
Table 3: Determinants of divorce risk for birth cohorts 1939-1961: Partial likelihood estimations of parameters using the Cox model

\begin{tabular}{|c|c|c|c|c|c|c|c|c|c|}
\hline & M 1 & M 2 & M 3 & M 4 & M 5 & M 6 & M 7 & M 8 & M 9 \\
\hline $\begin{array}{l}\text { GDR } \\
\text { (|t|-value) }\end{array}$ & $\begin{array}{l}1.263 * * \\
(2.589)\end{array}$ & $\begin{array}{l}1.240^{*} \\
(2.376)\end{array}$ & $\begin{array}{l}1.274 * * \\
(2.687)\end{array}$ & $\begin{array}{l}1.226^{*} \\
(2.163)\end{array}$ & $\begin{array}{l}0.603 * * * \\
(3.298)\end{array}$ & $\begin{array}{l}* 3.779 \\
(1.631)\end{array}$ & $\begin{array}{l}1.428 * * \\
(2.978)\end{array}$ & $\begin{array}{l}1.430 * * * \\
(3.392)\end{array}$ & $\begin{array}{l}* 6.837^{*} \\
(2.329)\end{array}$ \\
\hline $\begin{array}{l}\text { Divorced parents } \\
\text { (|t|-value) } \\
\text { Divorced parents*GDR } \\
(|\mathrm{t}| \text {-value })\end{array}$ & $\begin{array}{l}2.321 * * * \\
(4.216) \\
0.553^{*} \\
(2.028)\end{array}$ & $\begin{array}{l}* 2.387 * * * \\
(4.354) \\
0.547 * \\
(2.066)\end{array}$ & $\begin{array}{l}* 2.319 * * * \\
(4.210) \\
0.536 * \\
(2.136)\end{array}$ & $\begin{array}{l}* 2.324 * * * \\
(4.218) \\
0.554 * \\
(2.020)\end{array}$ & $\begin{array}{l}* 2.035 * * * \\
(3.531) \\
0.609 \\
(1.693)\end{array}$ & $\begin{array}{l}* 1.874 * * \\
(2.606) \\
0.671 \\
(1.229)\end{array}$ & $\begin{array}{l}2.237 * * * \\
(4.008) \\
0.604 \\
(1.723)\end{array}$ & $\begin{array}{l}* 4.189 * * * \\
(4.189) \\
0.558 * \\
(2.001)\end{array}$ & $\begin{array}{l}* 1.786 * \\
(2.396) \\
0.749 \\
(0.887)\end{array}$ \\
\hline $\begin{array}{l}\text { Widowed parent } \\
\text { Unknown parent }\end{array}$ & $\begin{array}{l}0.825 \\
1.115\end{array}$ & $\begin{array}{l}1.037 \\
1.125\end{array}$ & $\begin{array}{l}0.824 \\
1.192\end{array}$ & $\begin{array}{l}0.839 \\
1.140\end{array}$ & $\begin{array}{l}0.848 \\
1.081\end{array}$ & $\begin{array}{l}0.726 \\
1.134\end{array}$ & $\begin{array}{l}0.846 \\
1.121\end{array}$ & $\begin{array}{l}0.847 \\
1.125\end{array}$ & $\begin{array}{l}0.994 \\
1.185\end{array}$ \\
\hline $\begin{array}{l}\text { Married 1970-79 } \\
\text { Married 1980-89 }\end{array}$ & & $\begin{array}{l}1.861 * * * \\
2.404 * * *\end{array}$ & & & & & & & $\begin{array}{l}2.063 * * * \\
3.555 * * *\end{array}$ \\
\hline $\begin{array}{l}\text { Father: good education } \\
\text { Mother: good education }\end{array}$ & & & $\begin{array}{l}1.381^{* *} \\
1.257\end{array}$ & & & & & & $\begin{array}{l}1.514^{* *} \\
1.385^{*}\end{array}$ \\
\hline $\begin{array}{l}\text { Wives' educ.: low } \\
\text { Wives' educ.: middle } \\
\text { Husbands' educ.>wives' } \\
\text { Husbands' educ.<wives' }\end{array}$ & & & & $\begin{array}{l}0.944 \\
1.016 \\
1.241 \\
1.137\end{array}$ & & & & & $\begin{array}{l}1.347 \\
0.989 \\
1.151 \\
1.234\end{array}$ \\
\hline $\begin{array}{l}\text { Catholic } \\
\text { Catholic*GDR } \\
\text { Protestant } \\
\text { Protestant*GDR }\end{array}$ & & & & & $\begin{array}{l}0.334^{* * *} \\
1.998 \\
0.405^{* * * *} \\
1.553^{*}\end{array}$ & & & & \\
\hline $\begin{array}{l}\text { Husbands' marriage age } \\
\text { Husbands' marr. } \\
\text { age*GDR } \\
\text { Wives' marriage age } \\
\text { Wives'marr. age*GDR }\end{array}$ & & & & & & $\begin{array}{l}0.959 \\
1.030 \\
0.989 \\
0.925^{*}\end{array}$ & & & $\begin{array}{l}0.962 \\
1.016 \\
0.963 \\
0.929\end{array}$ \\
\hline $\begin{array}{l}\text { Child before marriage } \\
\text { Child before marr.*GDR } \\
1^{\text {st }} \text { child (time dep.) } \\
1^{\text {st }} \text { child (time dep.)*GDR }\end{array}$ & & & & & & & $\begin{array}{l}1.017 \\
0.920 \\
0.399 * * * \\
1.287\end{array}$ & & $\begin{array}{l}0.979 \\
0.938 \\
0.412 * * * \\
1.246\end{array}$ \\
\hline $\begin{array}{l}1977 \text { (time dep.)*FRG } \\
1978 \text { (time dep.)*FRG }\end{array}$ & & & & & & & & $\begin{array}{l}0.797 \\
1.942 * *\end{array}$ & $\begin{array}{l}0.750 \\
2.298^{* *}\end{array}$ \\
\hline $\begin{array}{l}\text { Number of marriages } \\
\text { Number of episodes }\end{array}$ & $\begin{array}{l}4238 \\
4238\end{array}$ & $\begin{array}{l}4238 \\
4238\end{array}$ & $\begin{array}{l}4238 \\
4238\end{array}$ & $\begin{array}{l}4238 \\
4238\end{array}$ & $\begin{array}{l}4238 \\
4238\end{array}$ & $\begin{array}{l}4140 \\
4140\end{array}$ & $\begin{array}{l}4232 \\
7289\end{array}$ & $\begin{array}{l}4238 \\
8994\end{array}$ & $\begin{array}{l}4136 \\
11844\end{array}$ \\
\hline $\begin{array}{l}\text { - log-likelihood } \\
\text { LR }\end{array}$ & $\begin{array}{l}4459.66 \\
19.62\end{array}$ & $\begin{array}{l}4433.7 \\
71.54\end{array}$ & $\begin{array}{l}4451.97 \\
35.00\end{array}$ & $\begin{array}{c}4456.98 \\
24.98\end{array}$ & $\begin{array}{l}4434.13 \\
70.68\end{array}$ & $\begin{array}{l}3928.94 \\
37.90\end{array}$ & $\begin{array}{l}4407.04 \\
124.86\end{array}$ & $\begin{array}{l}4452.56 \\
33.82\end{array}$ & $\begin{array}{l}3821.82 \\
252.14\end{array}$ \\
\hline
\end{tabular}

Notes: $* * *$ significant for $\mathrm{p}=.001 ; * *$ significant for $\mathrm{p}=.01 ; *$ significant for $\mathrm{p}=.05$. The reported figures are the (exponentiated) $\alpha$-coefficients for the covariates. $(\alpha-1) \times 100=$ percentage effect of a covariate on the divorce risk. LR is the likelihood ratio statistic with the GDR dummy in the reference Cox model. 
Table 4: Interaction between type of parental family and country of origin

\begin{tabular}{llll}
\hline & (a) complete families & (b) divorced parents & (b)/(a) \\
\hline Model 1: & & & \\
- West Germany & 1 & 2.321 & 2.321 \\
- East Germany & 1.263 & 1.621 & 1.283 \\
\hline Model 5: & & & \\
- West Germany & 1 & 2.035 & 2.035 \\
- East Germany & 0.603 & 0.747 & 1.239 \\
\hline Model 6: & & & \\
- West Germany & 1 & 1.874 & 1.874 \\
- East Germany & 3.779 & 4.752 & 1.257 \\
\hline Model 7: & & & \\
- West Germany & 1 & 2.237 & 2.237 \\
- East Germany & 1.428 & 1.929 & 1.351 \\
\hline Model 9: & & & \\
- West Germany & 1 & 1.647 & 1.647 \\
- East Germany & 2.532 & 9.146 & \\
\hline
\end{tabular}

Note: Interaction effects are computed from the estimated coefficients in Table 3. 
Table 5: Determinants of divorce risk for birth cohorts 1939-1961: Partial likelihood estimations of parameters using the Cox model

\begin{tabular}{lll}
\hline & West Germany & East Germany \\
\hline Divorced parents & $3.313 * *$ & 1.730 \\
Widowed parent & 1.256 & 0.870 \\
Unknown parent & 1.009 & 1.195 \\
\hline Married 1970-79 & $2.819 * * *$ & $1.362^{*}$ \\
Married 1980-89 & $3.718^{* * *}$ & $1.909 * * *$ \\
& & \\
Married 1970-79*div. parents & 0.742 & 0.718 \\
(|t|-value) & $(0.646)$ & $(0.527)$ \\
Married 1980-89*div. parents & 0.471 & 0.405 \\
(|t|-value) & $(1.174)$ & $(0.819)$ \\
\hline Number of marriages & 2646 & 1592 \\
- log-likelihood & 2129.59 & 1915.34 \\
LR & 1.46 & 2.06 \\
\hline
\end{tabular}

Notes: *** significant for $\mathrm{p}=.001 ; * *$ significant for $\mathrm{p}=.01$; * significant for $\mathrm{p}=.05$. The reported figures are the (exponentiated) $\alpha$-coefficients for the covariates. $(\alpha-1) \times 100=$ percentage effect of a covariate on the divorce risk. LR is the likelihood ratio statistic with a reference Cox model without interaction terms. 
Table 6: Interaction between type of parental family and cohorts

\begin{tabular}{llll}
\hline & (a) complete families & (b) divorced parents & (b)/(a) \\
\hline West Germany: & & & \\
- before 1970 & 1 & 3.313 & 3.313 \\
$-1970-79$ & 2.819 & 6.930 & 2.458 \\
- 1980-89 & 3.718 & 5.801 & 1.560 \\
\hline East Germany: & & & \\
- before 1970 & 1 & 1.730 & 1.730 \\
- 1970-79 & 1.362 & 1.692 & 1.242 \\
- 1980-89 & 1.909 & 1.338 & 0.701 \\
\hline
\end{tabular}

Note: Interaction effects are computed from the estimated coefficients in Table 5. 
Figure 1: Divorces in Germany per 10.000 inhabitants

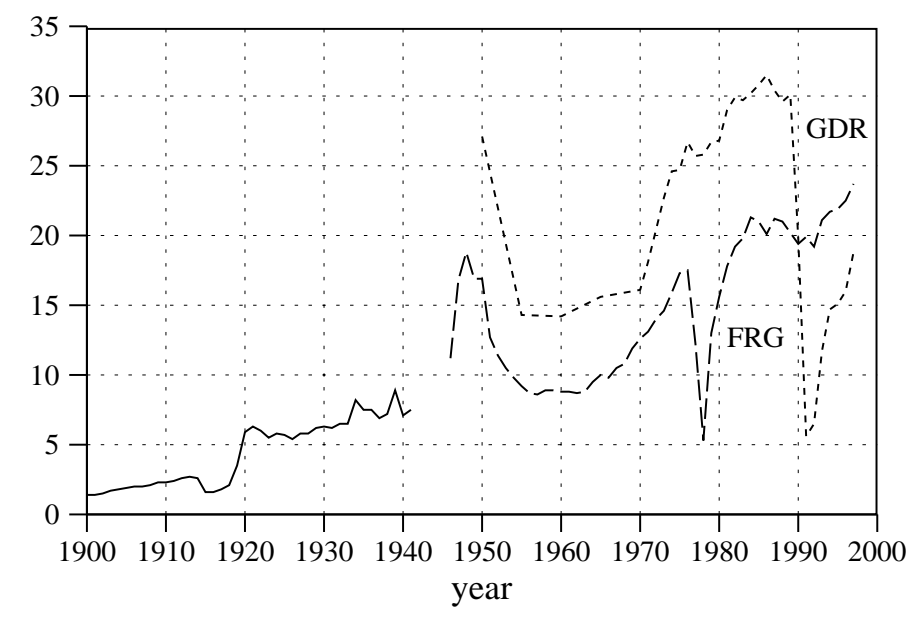


Figure 2: Proportion of still-married couples by marriage duration for four different types of family background in West Germany (Kaplan-Meier estimates)

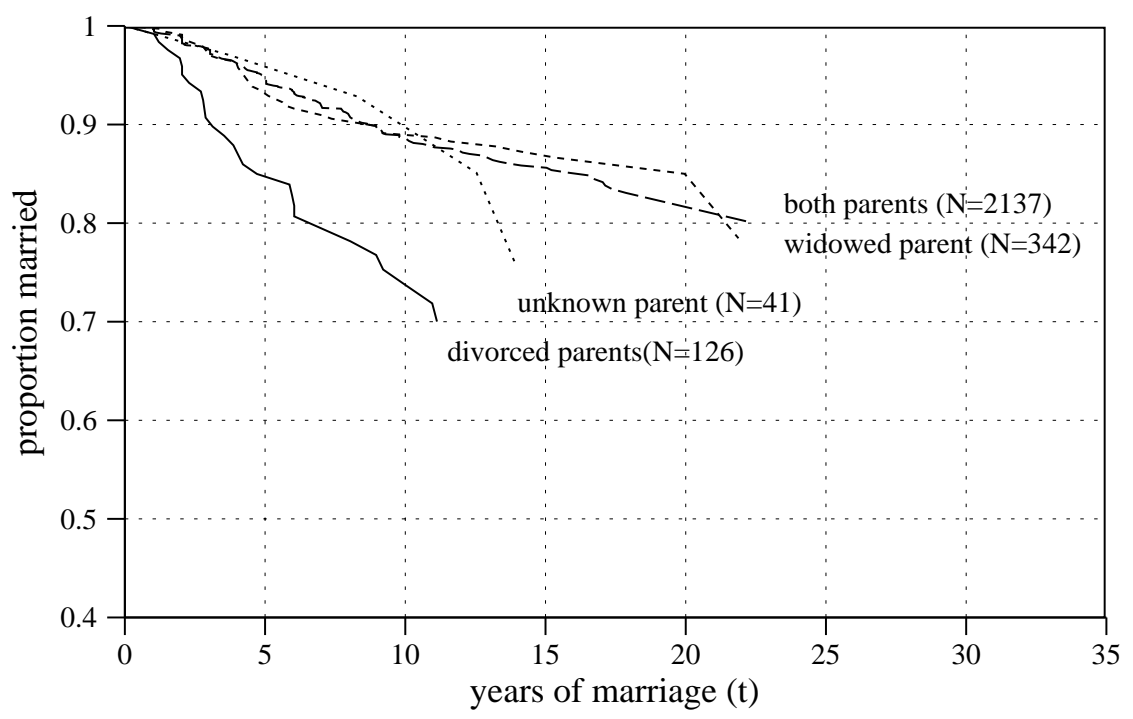

Log-Rank $($ Savage $)=0.000 ;$ Wilcoxon $($ Breslow $)=0.000$ 
Figure 3: Proportion of still-married couples by marriage duration for four different types of family background in East Germany (Kaplan-Meier estimates)

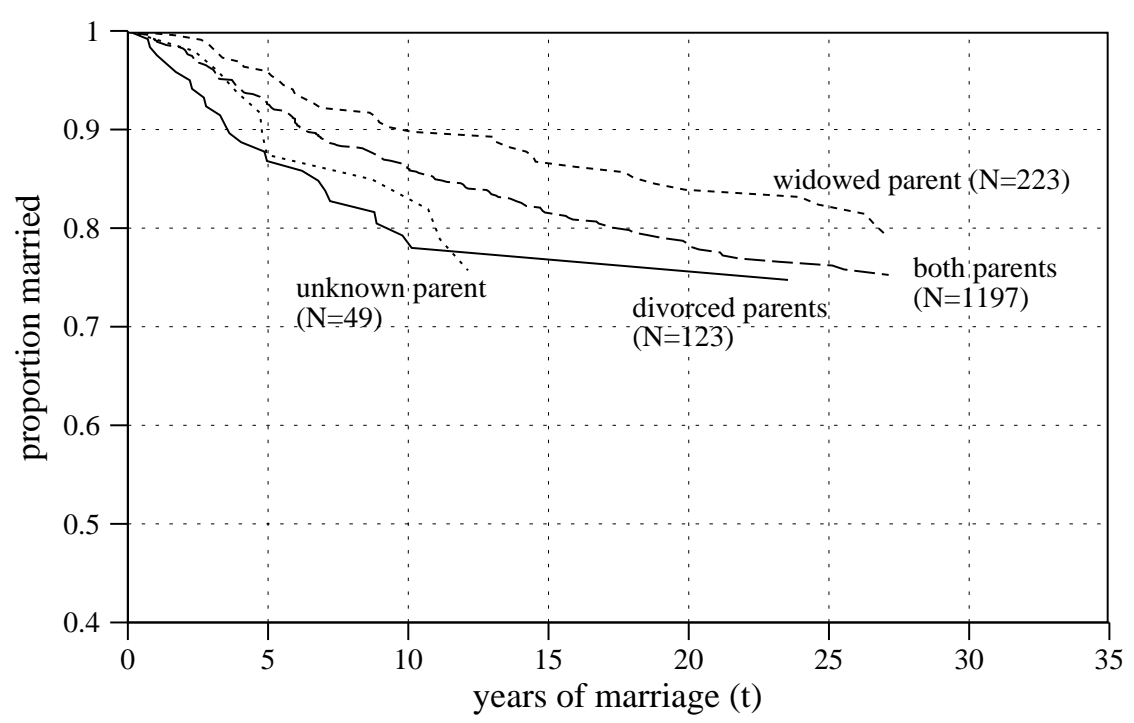

Log-Rank $($ Savage $)=0.174 ;$ Wilcoxon $($ Breslow $)=0.052$ 